\title{
SERTIFIKAT HAK ATAS TANAH DALAM KEPASTIAN HUKUM PENDAFTARAN TANAH
}

\author{
Rezeki Aldila Rajab, Bambang Eko Turisno, Anggita Doramia Lumbanraja \\ Program Studi Magister Kenotariatan \\ Fakultas Hukum, Universitas Diponegoro \\ E-mail : rezekialdilaaldila@gmail.com
}

\begin{abstract}
Achieving a legal certainty requires land registration. In order to achieve legal certainty, land registration is needed. The registration of land carried out is an attempt to provide legal certainty and protection to the holders of rights over a parcel of land and other registered rights so that the party proving is the party's owner of the said parcel of land. The purpose of this study was to determine the legal certainty of ownership of land rights certificates in land registration based on several existing laws and regulations. The research method used in this study is normative juridical. The result of this research is that to obtain legal certainty, a person must have a certificate as proof of ownership of the land rights. Certificate as a strong proof in this case as long as it cannot be proven otherwise physical and juridical contained there in must be accepted as correct. If a dispute in the future occurs, the settlement of proof of land rights certificate is carried out in court by the judge's judgment.
\end{abstract}

\section{Keywords: certificate; legal certainty ; land r}

\section{egistration}

\begin{abstract}
Tercapainya suatu kepastian hukum maka diperlukannya pendaftaran tanah. Pendaftaran tanah yang dilakukan merupakan suatu usaha untuk memberikan kepastian dan perlindungan hukum kepada pemegang hak atas suatu bidang tanah dan hak-hak lain yang terdaftar sehingga pihak yang membuktikan adalah benar pemilik atas bidang tanah tersebut. Tujuan Penelitian ini untuk mengetahui jaminan kepastian hukum kepemilikan sertifikat hak atas tanah dalam pendaftaran tanah berdasarkan beberapa peraturan perundang-undangan yang ada. Metode penelitian yang digunakan dalam penelitian ini adalah yuridis normatif. Hasil dari penelitian ini adalah bahwa untuk memperoleh kepastian hukum maka seseorang harus memiliki sertifikat sebagai alat bukti atas kepemilikan hak atas tanah tersebut. Sertifikat sebagai alat pembuktian yang kuat dalam hal ini selama tidak dapat dibuktikan sebaliknya data fisik dan data yuridis yang tercantum di dalamnya harus diterima sebagai data yang benar. Apabila dikemudian hari terjadi sengketa maka penyelesaian pembuktian sertifikat ha katas tanah tersebut dilakukan di pengadilan oleh pertimbangan hakim.
\end{abstract}

Kata kunci : sertifikat; kepastian hukum ; pendaftaran tanah 


\section{A. Pendahuluan}

Dalam Undang-Undang Dasar Tahun 1945 Pasal 28 D Ayat (1) disebutkan bahwa "Setiap orang berhak atas pengakuan, jaminan, perlindungan dan kepastian hukum yang adil serta perlakuan yang sama di hadapan hukum"(Undang-Undang Dasar Republik Indonesia Tahun 1945, 1945). Dalam Pasal 3 Ayat (3) Undang-Undang 1945 kewenangan pemerintah dalam mengatur bidang pertanahan menegaskan bahwa bumi, air dan kekayaan alam yang terkandung di dalamnya dikuasai oleh negara untuk dipergunakan bagi sebesar-besarnya kemakmuran rakyat kemudian hari yang dikukuhkan dalam Undang-Undang Nomor 5 Tahun 1960 tentang Peraturan Dasar Pokok-Pokok Agraria (lembaran Negara 1960-104) atau disebut juga Undang-Undang Pokok Agraria (UUPA). Hal ini dapat dilihat diberbagai peraturan Pemerintah, Keputusan Presiden, peraturan Presiden, dan peraturan yang diterbitkan oleh pimpinan instansi teknis di bidang pertanahan. (Hadisiswati, 2014).

Ketentuan dalam Buku II KUH Perdata dalam Pasal 506 menjelaskan mengenai barang tak bergerak yaitu termasuk di dalam nya adalah tanah. (Kitab Undang-Undang Hukum Perdata, 1937).

Dalam bukunya Adrian Sutendi, Jan Michiel Otto berpendapat bahwa kepastian hukum harus memenuhi syarat-syarat sebagai berikut: Memiliki aturan hukum yang jelas dan konsisten, dalam instansi pemerintah diterapkan aturan hukum yang konsisten, tunduk dan taat terhadapnya, masyarakat harus menyesuaikan kebiasaan mereka terhadap aturan hukum tersebut, hakim yang mandiri, tidak berpihak dan menerapkan aturan hukum secara konsisten serta jeli dalam menyelesaikan sengketa hukum dan putusan pengadilan secara konkrit.(Sutedi, 2011). Kepastian hukum adalah hal yang dapat ditentukan dari hukum dalam hal-hal yang konkrit. Pihak-pihak pencari keadilan ingin mengetahui bahwa seperti apa hukum dalam suatu keadaan atau hal tertentu, sebelum dimulainya dengan perkara. Sehingga keamanan hukum berarti melindungi para pihak terhadap kesewenang-wenangan hakim (Soerodjo, 2003). Sertifikat merupakan keterangan tertulis yang dimiliki oleh orang yang berwenang digunakan sebagai alat pembuktian.

Awal mula pendaftaran tanah diadakan menurut ketentuan Peraturan Pemerintah (PP) Nomor 10 Tahun 1961 tentang pendaftaran tanah. Namun, karena PP ini belum maksimal akibat beberapa kendala yaitu keterbatasan dana dan tenaga sehingga penguasaan tanah- tanah sebaian besar tidak di dukung oleh alat pembuktian yang memadai. Selain itu PP ini belum cukup memberikan kemungkinan terlaksananya pendaftaran tanah dalam waktu singkat dan 
hasil yang memuaskan. Dalam mendaftarkan tanah tidak ada batas waktu setelah peralihan hak, selain itu Pejabat Pembuat Akta Tanah tidak harus mendaftar tetapi bisa juga pemilik baru dari hak atas tanah sehingga seringkali tanahnya tidak didaftarkan. Untuk memperbaiki kelemahan ini maka dikeluarkan peraturan mengenai pendaftaran tanah yang baru untuk menyempurnakan peraturan pendaftaran tanah sebelumnya (Aprini, 2007).

Dalam Pasal 19 UUPA ayat (1) dasar pendaftaran tanah dinyatakan yaitu untuk memperoleh kepastian hukum maka Pemerintah mengadakan pendaftaran tanah di seluruh wilayah Republik Indonesia sesuai ketentuan yang diatur oleh peraturan pemerintah dan ayat (2) rangkaian pendaftaran tanah yaitu pengukuran, pemetaan, pembukuan tanah, pendaftaran hak-hak atas tanah serta peralihan atas adanya hak tersebut dan pemberian surat-surat tanda bukti hak yang berlaku sebagai alat pembuktian yang otentik (Undang-Undang Pokok Agraria No.5 Tahun 1960, 1960).

Kepada pemegang hak atas tanah yang didaftar akan diberikan surat tanda bukti hak yang disebut sertifikat sebagai hasil dari proses pendaftaran tanah. Sertifikat merupakan satu lembar dokumen yang memuat data yuridis dan data fisik yang diperlukan dari suatu bidang tanah yang didaftar sesuai dengan PP Nomor 24 Tahun 1997 (Parhi \& Kumar, 1997).

Di Indonesia, pendaftaran tanah menganut sistem negatif. Tetapi bukan sistem pendaftaran negatif murni, ketentuan di dalam Pasal 19 ayat (2) huruf c UUPA jo Pasal 17 ayat (1) PP Nomor 24 Tahun 1997, petugas pendaftaran tanah (Kantor Pertanahan) dalam melakukan pendaftaran tanah melakukan pengukuran, petugas akan mencari informasi mengenai subyek dan obyek yang didaftarkan. Petugas pendaftaran tanah bersikap aktif, mereka tidak hanya mempercayai informasi dari pemohon sertifikat. Sehingga dikatakan sebagai sistem pendaftaran tanah negative yang berunsur positif (Harsono, 1999).

Dalam pendaftaran tanah pada sistem publikasi negatif yang diperlukan untuk sahnya pelaksanaan hukum yaitu untuk menentukan perpindahan hak kepada pihak lain sebagai pembeli.

Di dalam sistem ini berlaku asas nemo plus juris yaitu seseorang tidak berhak menyerahkan atau memindahkan hak melebihi apa yang ia miliki. Kebenaran data yang dilampirkan tidak boleh dipercaya langsung karena Negara tidak memberi jaminan atas kebenaran atas data tersebut. Sistem publikasi yang digunakan adalah sistem negatif yang mengandung unsur positif, hal ini dituangkan di dalam sistem publikasi negatif berunsur positif 
akan menghasilkan surat-surat tanda bukti hak seseorang yang berlaku dan sebagai alat pembuktian yang kuat, hal ini diatur di dalam UUPA dan PP No.24 Tahun 1997 tentang pendaftaran tanah (Harsono, 2004). Kepemilikan hak atas tanah seseorang dapat dinikmati manfaatnya dan digunakan sesuai dengan peruntukkannya (Suhariningsih, 2009).

Di dalam prakteknya kasus sertifikat tanah masih sering terjadi sengketa karena banyak masyarakat yang memiliki cara untuk menyerobot tanah orang lain sehingga kasus tersebut sampai ke pengadilan. Sehingga untuk memberikan kepastian dan perlindungan hukum di bidang pertanahan maka pemegang hak atas suatu bidang tanah serta hak-hak lain yang terdaftar diberikan sertifikat hak atas tanah untuk apabila dikemudian hari terjadi sengketa dapat membuktikan dirinya sebagai pemilik atas tanah tersebut.

Akibat dari kasus sengketa tersebut dapat menimbulkan konflik yang berkepanjangan antar masyarakat. Yang menjadi pertanyaan bahwa siapakah yang lebih berhak atas tanah tersebut sehingga para pihak yang merasa dirinya sebagai pemilih kah atas tanah masingmasing akan membuktikan bahwa mereka yang lebih berhak atas tanah tersebut.

Sehingga untuk tercapainya jaminan kepastian hukum dan kepastian hak atas tanah, masyarakat harus mendaftarkan tanahnya untuk memperoleh sertifikat hak atas tanah sebagai alat pembuktian yang kuat atas kepemilikan tanah tersebut.

Berdasarkan uraian diatas, maka permasalahan yang dikaji dalam penelitian ini adalah mengenai bagaimana jaminan kepastian hukum kepemilikan sertifikat hak atas tanah dalam pendaftaran tanah berdasarkan Peraturan Pemerintah No. 24 Tahun 1997 tentang pendaftaran tanah, dan bagaimana penerapan Peraturan Pemerintah No. 24 Tahun 1997 tentang pendaftaran tanah dalam penyelesaian pembuktian sertifikat hak atas tanah.

Penelitian ini memiliki perbedaan dari penelitian-penelitian sebelumnya seperti penelitian yang dilakukan oleh Fitrah Oeloem yang membahas permasalahan mengenai kekuatan sertifikat sebagai dasar kepemilikan hak atas tanah dan kepastian hukum setelah terbitnya sertifikat bagi pemegang hak atas tanah (Oeloem, 2015). Selanjutnya penelitian yang dilakukan oleh Christiana Tri Budhayati yang membahas permasalahan mengenai jaminan kepastian hukum dan pemilikan ha katas tanah dan Lembaga rechtsverwerking sebagai sarana pemberian kepastian hukum dan perlindungan hukum kepada pemegang hak atas tanah (Budhayati, 2018). Selain dua penelitian tersebut, penulis memberikan salah satu contoh jurnal lain sebagai bentuk orisinalitas penelitian yang dilakukan oleh penulis, yaitu penelitian yang dilakukan oleh Indri 
Hadisiswati yang membahas mengenai kepastian hukum serta perlindungan hukum hak atas tanah (Hadisiswati, 2014).

\section{B. Metode Penelitian}

Metode yang digunakan dalam penelitian ini adalah dilakukan dengan menggunakan jenis Studi Kepustakaan dengan pendekatan perundang-undangan dengan bahan hukum yang terdiri dari bahan hukum primer yang terdiri dari perundang-undangan dan putusan hakim, selanjutnya bahan hukum sekunder yang terdiri dari publikasi hukum yang meliputi buku-buku, jurnal hukum serta tulisan lainnya.

\section{Hasil Dan Pembahasan}

\section{Sertifikat Hak Atas Tanah Dalam Kepastian Hukum Pendaftaran Tanah}

Kepemilikan sertifikat hak atas tanah sangatlah penting untuk memberikan perlindungan terhadap rakyat Indonesia mengenai hak atas tanah yang bersangkutan serta untuk menciptakan tujuan dari pembentukan Undang-Undang Pokok Agraria yaitu meletakkan dasar-dasar untuk memberikan kepastian hukum. Dalam hal untuk dapat mewujudkan kepastian hukum tersebut diselenggarakan pendaftaran tanah. Hal ini dipertegas di dalam Pasal 19 ayat (1) Undang-Undang Pokok Agraria (UUPA) diadakan pendaftaran tanah oleh pemerintah di seluruh wilayah Republik Indonesia sesuai dengan ketentuan yang diatur dalam Peraturan Pemerintah untuk menjamin kepastian hukum dan ayat (2) Pengukuran, perpetaan dan pembukuan tanah, pendaftaran atas hk-hak atas tanah dan peralihan hak-hak tersebut, pemberian surat tanda bukti hak yang berlaku sebagai alat bukti yang kuat merupakan rangkaian dari pendaftaran tanah (Harsono, 2011). Tujuan pendaftaran tanah untuk memberikan kepastian hukum dan perlindungan hukum kepada pemegang hak atas tanah. Kepastian hukum yang terdiri dengan obyek, subyek dan hukumnya yang berkaitan dengan konstruksi hukum. Hal ini disebutkan di dalam Pasal 19 ayat (1) UUPA jo Pasal 3 PP Nomor 24 Tahun 1997 (Budhayati, 2018)

Pendaftaran tanah yang berlaku di Indonesia yaitu sertifikat sebagai tanda bukti kepemilikan hak tidak berlaku mutlak, dalam hal ini berarti bahwa sertifikat tanda bukti hak masih dapat dibatalkan apabila sertifikat tersebut cacat hukum. Sertifikat merupakan surat pembuktian tertulis terhadap kepemilikan hak atas tanah yang dapat memberikan jaminan 
hukum. Dalam hal sertifikat yang diperoleh dengan biaya cukup tinggi dan prosedur yang cukup rumit belum bias memberikan sebuah kepastian hukum bagi masyarakat. Meskipun tanah tersebut telah memperoleh sertifikat sebagai alat bukti kepemilikan hak atas tanah, pihak yang merasa memiliki atau mengklaim tanah tersebut, masih dapat mengajukan keberatan hukum dengan melakukan gugatan atas hak kepemilikan tanah tersebut serta dapat mengupayakan pembatalan sertifikat yang telah diterbitkan atas dasar adanya putusan hakim yang telah berkekuatan hukum tetap (Oeloem, 2015)

Dalam menentukan jaminan bahwa seseorang berhak atas kepemilikan hak atas tanah dengan dilakukannya pendaftaran tanah. Pendaftaran tanah itu sangat penting karena untuk memberikan kejelasan atau keterangan agar tidak menimbulkan permasalahan dalam bidang pertanahan terutama terhadap status tanah.

Di dalam penjelasan UUPA No. 5 Tahun 1960 bahwa kegiatan pendaftaran tanah disebut dengan istilah kadaster hak terdiri atas peta dan daftar mengenai bidang tanah yang menguraikan keadaan hukum bidang tanah tersebut, mengenai luas dan lokasinya, mengenai subyek haknya, riwayat pemilik tanah serta perbuatan hukumnya. Untuk memberikan informasi yang lengkap mengenai bidang tanah yang dipertegas dan dimungkinkannya pembukuan bidang tanah yang data fisik dan data yuridisnya belum lengkap atau masih disengketakan, walaupun untuk tanah-tanah demikian belum ada sertifikatnya sebagai tanda bukti haknya hal ini merupakan tujuan pendaftaran tanah (Thalib, 1985).

Dalam pelaksanaan pendaftaran tanah dengan adanya peran masyarakat dalam kegiatan pendaftaran tanah akan membuka banyak kemudahan sehingga masyarakat lebih bergairah untuk mendaftarkan tanahnya, hal yang paling penting untuk membuktikan adanya hak atas tanah dengan melakukan pendaftaran hak atas tanah dengan meminta kepada Kantor Pertanahan agar tanah yang dimiliki atau dikuasai oleh seseorang mapun badan hukum dicatat identitasnya di Kantor Pertanahan dan kepada pemegang hak yang sah.

Hal yang terpenting dalam pendaftaran tanah yaitu apabila tanah yang dikuasai tersebut mempunyai catatan identitas tanah yang memuat mengenai jenis haknya, luasnya, keadaanya, batas dan letaknya, serta siapa yang memiliki atau menguasai dan mempunyai cri khas yang lain (Siahaan, 2003).

Dalam Pasal 19 Undang-Undang Pokok Agraria (UUPA) mempunyai tujuan yaitu untuk menjamin kepastian hukum oleh pemerintah diadakan pendaftaran tanah di seluruh wilayah Republik Indonesia menurut ketentuan-ketentuan yang diatur dalam Peraturan Pemerintah. Namun dalam hal ini terjadi pertentangan antara Pasal 19 Undang-Undang 
Pokok Agraria (UUPA) dengan PP No.24 Tahun 1997 mengenai jaminan kepastian hukum, dimana dikatakan bahwa di dalam Pasal 19 UUPA untuk menjamin kepastian hukum dengan melakukan pendaftaran tanah dan hasil dari pendaftaran tanah inilah yang berupa sertifikat yang dapat menjamin suatu hak kepemilikan seseorang mengenai suatu bidang tanah. Tetapi, di dalam Pasal 32 PP No.24 Tahun 1997 dikatakan bahwa sertifikat sebagai suatu jaminan kepastian hukum tersebut masih dapat diganggu gugat oleh pihak lain yang merasa mempunyai hak atas tanah itu dan pihak lain tersebut bisa membuktikan sebaliknya. Maka dalam hal ini untuk tercapainya jaminan kepastian hukum tersebut setelah melakukan pendaftaran tanah dan hasil yang diperoleh dari pendaftaran tanah tersebut berupa sertifikat. Sertifikat inilah yang sebenarnya menjadi alat pembuktian apabila terjadi suatu sengketa. Sehingga letak dari suatu kepastian hukum tersebut yaitu dimana Hakim dapat memeriksa dan memutus suatu perkara sengketa dengan melihat bahwa diantara dua pihak yang bersengketa untuk membuktikan masing-masing di muka pengadilan. Yang dibuktikan oleh pihak-pihak yang bersengketa tersebut mengenai obyek pendaftaran tanah nya yang terdiri dari jenis hak atas tanah, pemegang haknya, keterangan fisik tentang tanah, beban diatas tanah, dan peristiwa hukum yang terjadi, maka Hakim dapat memutuskan siapa pemilik hak atas suatu tanah tersebut setelah membuktikan obyek pendaftaran tanah tersebut.

Untuk membuktikan siapa yang berhak atas suatu bidang tanah tersebut maka yang berhak memutus yaitu pengadilan. Diadakannya perubahan dan pembetulan apabila tidak sesuai nya pendaftaran tanah.

Pembuktian dari kepemilikan atas suatu kebendaan maka harus adanya alat bukti yang kongkrit, dan alat bukti yang lazim berlaku yaitu bukti administratif, bukti phisik, dan bukti yuridis, termasuk sebagai kepemilikan tanah. Jika tidak ada alat bukti yang syah, maka secara bukti administratif dan yuridis, seseorang yang memiliki tanah dan segala kebendaannya dianggap tidak pernah ada. Sedangkan apabila terdapat alat bukti yang syah masih dapat diadakan penyangkalan atau dianggap tidak sah oleh pihak lain selama pihak yang menyangkal tersebut bisa menunjukkan alat bukti yang lengkap atau sebaliknya. Setelah diadu kekuatan pembuktiannya, maka pemegang alat bukti yang paling lengkap dan cara peralihan hak serta pembuatan alat bukti inilah sebagai pemilik sah sebenarnya (Iskandar syah, 2015).

\section{Penerapan Pendaftaran Tanah Dalam Penyelesaian Permasalahan Pembuktian Sertifikat Hak Atas Tanah}


Sertifikat merupakan tanda bukti yang kuat, dalam hal ini selama tidak dapat dibuktikan sebaliknya data fisik dan data yuridis yang tercantum di dalamnya harus diterima sebagai data yang benar. Apabila selama tidak dapat dibuktikan kepada pihak yang menyangkal, maka data yang tercantum sebagai data fisik dan data yuridis dalam sertifikat harus diterima sebagai data yang benar, baik di dalam perbuatan hukum sehari-hari ataupun dalam berperkara di pengadilan hal ini terdapat di penjelasan Pasal 32 ayat (1) PP No. 24 Tahun 1997 (Soerodjo, 2003b).

Maka dari hal tersebut sertifikat bukan sebagai alat bukti yang mutlak karena dalam pelaksanaannya kemungkinan masih dapat dinyatakan batal atau tidak memiliki kekuatan hukum yang disampaikan oleh putusan pengadilan. Sehingga pihak yang mempunyai kepentingan dapat mengajukan gugatan ke pengadilan agar pengadilan dapat memutuskan sertifikat hak atas tanah tertentu tidak memiliki kekuatan hukum.

Dalam penjelasan Pasal 32 ayat (2) PP No.24 Tahun 1997 diuraikan lebih lanjut bahwa dalam sistem publikasi negatif memiliki kelemahan bahwa apabila pihak yang Namanya tercantum sebagai pemegang hak dalam buku tanah dan sertfikat maka kemungkinan menghadapi gugatan dari pihak lain yang merasa mempunyai tanah itu. Hal ini dimana pihak yang satu tetap pada prinsipnya sedangkan pihak yang lain menunjukkan itikad baik kepada pihak tersebut bahwa sebagai pemegang hak dengan adanya sertifikat sebagai alat buktinya.

Untuk mengatasi kelemahan hukum tanah Indonesia maka berdasakan hukum adat menggunakan lembaga " rechtsverwerking". Mengacu pada ketentuan tersebut bahwa batas waktu 5 tahun dapat berlaku apabila memenuhi 3 persyaratan yaitu pelaksanaan pendaftaran tanah dilakukan secara sah dan menghasilkan produk hukum yaitu sertifikat yang sesuai dengan ketentuan perundang-undangan yang berlaku, pelaksanaan pendaftaran tanah pertama dilakukan pengumuman terhadap tanah yang telah diteliti sebelum dibuatkannya pembukuan hak atas tanah. Jika pengumuman tidak sesuai dengan aturan atau tidak dilakukan maka dikatakan sebagai cacat hukum dalam proses pensertifikatan. Pemohon yang memiliki penguasaan tanah tersebut dengan itikad baik harus memenuhi syarat hukum mengenai itikad baik tersebut serta penguasaan tanah secara fisik/ sporadik oleh pemohon. Jika semua persyaratan tersebut tidak dipenuhi dalam kurun waktu 5 (lima) tahun maka tidak dapat diterapkan.

Dalam penerapan Pasal 32 ayat (2) PP No.24 Tahun 1997 terhadap kasus-kasus konkrit yang akan mempertimbangkan adalah hakim, terpenuhinya syarat-syarat bagi 
penerapannya sebagaimana halnya penerapan lembaga "rechtsverwerking"pada tanah-tanah adat karena pengaturannya masih dalam bentuk Peraturan Pemerintah. Untuk menimbang berat ringannya kepentingan pihak yang bersengketa maka Hakimlah yang mempunyai tugas tersebut serta dalam rangka hukum tanah nasional maka ketentuan ini perlu diatur dalam bentuk undang-undang (Harsono, 2005).

Dalam permasalahan pembuktian sertifikat hak atas tanah yang harus dibuktikan yaitu : Pertama Jenis Hak. Dari sertifikat dapat diketahui, apakah tanah tertentu yang disebut didalamnya berstatus Hak Milik atau Hak Guna Bangunan atau Hak Pakai atau Hak Pengelolaan. Dan berapa lama hak itu diberikan serta kapan berakhir (selain Hak Milik). Untuk mengetahui jenis hak itu karena ditulis di bagian sampul dalam sertfikat dan dikolom pertama bagian atas dari buku tanah. Kedua Pemegang Hak, di dalam kolom kedua di atas dari buku tanah dapat dibaca Nama pemegang hak. Apabila pemegang hak berganti, dan adanya pembagian waris, adanya hibah maka harus ditulis data yang baru dan data yang lama dicoret.

Ketiga, Keterangan Fisik. Dalam sertifikat terdapat surat ukur, maka untuk mengetahui sertifikat kita tahu bahwa tentang luas, panjang, lebar tanah. Selain itu dalam surat ukur juga digambarkan bentuk fisik tanah, apakah berupa segi enam atau segi empat dan sebagainya. Letak dan batas-batas tanah juga dijelaskan dalam sertifikat, dan keadaan tanah (misalnya : gunung atau rawa) dan bangunan yang berada di atas tanah itu, atau seperti ada Hak Sewa atau Hak Guna Bangunan. Dan kemungkinan di catat di dalam sertifikat dengan adanya sitaan atas perintah pengadilan.

Kelima, Peristiwa yang berhubungan dengan tanah. Hal yang berkaitan dengan tanah tertentu juga dicatat oleh KPT dalam sertifikat, Misalnya hibah atau jual beli atau lelang maupun inbreng (pemasukan) ke dalam suatu PT atau jika terjadi penyitaan maupun terjadinya pewarisan serta beban-beban yang disebutkan diatas dan penghapusannya (Perangin, 1986).

Dengan memperhatikan yurisprudensi Mahkamah Agung, telah ditegaskan mengenai instansi mana yang berwenang membatalkan sertifikat, yaitu : Putusan Mahkamah Agung No. 350K/Sip/1968 tanggal 3 Mei 1969. (Putusan Mahkamah Agung No.350K/Sip/1968, 1969). Untuk menyatakan bahwa batal sertifikat yang dikeluarkan oleh instansi agrarian secara sah bukan termasuk weweang dari pengadilan, melainkan semata-mata wewenangnya hanya administrasi, sehingga pihak yang dimenangkan oleh pengadilan wajib meminta 
pembatalan sertifikat itu kepada instansi Agraria berdasarkan putusan pengadilan yang diperolehnya itu.

Putusan Mahkamah Agung No. 716K/Sip/1973 tanggal 5 September 1973 (Putusan Mahkamah Agung No.716/Sip/1973, 1973) adalah Pengeluaran atau pencabutan dan pembatalan sertifikat merupakan wewenang dari kantor Pendaftaran Tanah dan Pengawasan Pendaftaran Tanah, bukan termasuk wewenang Pengadilan Negeri (Abdurrahman, 1983).

Dari dua Putusan Mahkamah Agung tersebut pengadilan harus menilai dari semua sudut pandang bukan hanya pada siapakah yang berhak atas sertifikat tersebut. Dalam meneliti, memeriksa dan membuktikan asal usul pemilikan tanah yang tercantum dalam sertifikat maka terlebih dahulu hakim melihat bahwa apakah keterangan dalam sertifikat itu benar atau tidak, serta dalam sertifikat tersebut apakah mempunyai kekuatan hukum atau tidak. Hakim dapat menganggap keterangan yang dituangkan dalam sertifikat sebagai hal yang benar, dan jika fakta nya benar maka akan mempunyai kekuatan hukum, dan adanya alat pembuktian lain yang lebih kuat yang dapat memberikan pembuktian (Ruchiyat, 1989).

\section{Simpulan}

Pembuktian sertifikat hak atas tanah yang harus dibuktikan yaitu : Pertama Jenis Hak. Dari sertifikat dapat diketahui, apakah tanah tertentu yang disebut didalamnya berstatus Hak Milik atau Hak Guna Bangunan atau Hak Pakai atau Hak Pengelolaan. Dan berapa lama hak itu diberikan serta kapan berakhir (selain Hak Milik). Untuk mengetahui jenis hak itu karena ditulis di bagian sampul dalam sertfikat dan dikolom pertama bagian atas dari buku tanah. Kedua Pemegang Hak, di dalam kolom kedua di atas dari buku tanah dapat dibaca Nama pemegang hak. Apabila pemegang hak berganti, dan adanya pembagian waris, adanya hibah maka harus ditulis data yang baru dan data yang lama dicoret.Ketiga, Keterangan Fisik. Dalam sertifikat terdapat surat ukur, maka untuk mengetahui sertifikat kita tahu bahwa tentang luas, panjang, lebar tanah. Selain itu dalam surat ukur juga digambarkan bentuk fisik tanah, apakah berupa segi enam atau segi empat dan sebagainya. Letak dan batas-batas tanah juga dijelaskan dalam sertifikat, dan keadaan tanah (misalnya : gunung atau rawa) dan bangunan yang berada di atas tanah itu, atau seperti ada Hak Sewa atau Hak Guna Bangunan. Dan kemungkinan di catat di dalam sertifikat dengan adanya sitaan atas perintah pengadilan.Kelima, Peristiwa yang berhubungan dengan tanah. Hal yang berkaitan dengan tanah tertentu juga dicatat oleh KPT dalam sertifikat, Misalnya hibah atau jual beli atau lelang maupun inbreng (pemasukan) ke 
dalam suatu PT atau jika terjadi penyitaan maupun terjadinya pewarisan serta beban-beban yang disebutkan diatas dan penghapusannya

\section{DAFTAR PUSTAKA}

\section{Buku}

Abdurrahman. (1983). Aspek tentang Hukum Agraria Seri Hukum Agraria V (Cetakan Ke). Bandung: Alumni.

Harsono, B. (1999). Hukum Agraria Indonesia: Sejarah Pembentukan Undang Undang Pokok Agraria, Isi Dan Pelaksanannya. Djambatan.

Harsono, B. (2004). Hukum Agraria Indonesia (Himpunan Peraturan Peraturan Hukum Tanah. Jakarta: Djambatan.

Harsono, B. (2005). Hukum AgrariaIndonesia: Sejarah Pembentukan Undang-Undang Pokok Agraria, Isi Dan Pelaksanaannya (Cetakan Ke). Jakarta: Djambatan.

Harsono, B. (2011). Hukum Agraria Indonesia: Himpunan Peraturan-Peraturan Hukum Tanah (Cetakan Ke). Jakarta: Djambatan.

Iskandar syah, M. (2015). Pembebasan Tanah untuk Pembangunan Kepentingan Umum. Jakarta: Permata Aksara.

Perangin, E. (1986). Praktek Pengurusan Sertifikat Hak Atas Tanah (Cetakan Ke). Jakarta: CV.Rajawali.

Ruchiyat, E. (1989). Sistem Pendaftaran Tanah Sebelum dan Sesudah Berlakunya UUPA (Cetakan $\mathrm{Ke})$. Bandung: Armico.

Siahaan, M. (2003). Perolehan Hak Atas Tanah dan Bangunan : Teori dan Praktek. Jakarta: PT. Raja Grafindo Persada.

Soekanto, S. (1986). Pengantar Penelitian Hukum. Jakarta: UI Press.

Soerodjo, I. (2003a). Kepastian Hukum Hak Atas Tanah di Indonesia. Surabaya: Arkola.

Soerodjo, I. (2003b). Kepastian Hukum Hak Atas Tanah Di Indonesia. Surabaya: Arkola.

Suhariningsih. (2009). Tanah Terlantar (Asas dan Pembaharuan Konsep Menuju Pernerbitan). 
Jakarta: Prestasi Pusaka.

Sutedi, A. (2011). Sertifikat Hak Atas Tanah. Jakarta: Sina Grafika.

Suteki., \& Taufani, G. (2018). Metodologi Penelitian Hukum( Filsafat, Teori dan Praktik). Dpeok: PT. Raja Granfindo.

Thalib, S. (1985). Hubungan Tanah Adat dengan Hukum Agraria di Minangkabau. Jakarta: Bina Aksara.

\section{Artikel Jurnal}

Budhayati, C. T. (2018). Jaminan Kepastian Kepemilikan Bagi Pemegang Hak Atas Tanah Dalam Pendaftaran Tanah Menurut UUPA. 2(April), 125-138.

Hadisiswati, I. (2014). Kepastian Hukum Dan Perlindungan Hukum Hak Atas Tanah. Ahkam: Jurnal Hukum Islam, 2(1). https://doi.org/10.21274/ahkam.2014.2.1.118-146

Oeloem, F. (2015). Jaminan Kepastian Hukum Hak Atas Tanah Dalam Sistem Pendaftaran Tanah Negatif Bertendensi Positif. 0-21.

\section{Undang-undang dan Peraturan}

Undang-Undang Dasar Republik Indonesia Tahun 1945. , (1945).

Undang-Undang Pokok Agraria No.5 Tahun 1960. , (1960).

Kitab Undang-Undang Hukum Perdata. , (1937).

Parhi, D. R., \& Kumar, B. Peraturan Pemerintah No.24 Tahun 1997. , 21 § (1997).

Putusan Mahkamah Agung No.350K/Sip/1968. , (1969).

Putusan Mahkamah Agung No.716/Sip/1973. , (1973).

\section{Tesis}

Aprini, E. (2007). Kepastian Hukum Sertifikat Hak atas Tanah Kaitannya dengan Ketentuan Pasal 32 ayat (2) Peraturan Pemerintah Nomor 24 Tahun 1997. Univeristas Diponegoro. 
